\title{
Effect of Storage Conditions on the Nutritional Quality of Protein Fortified Jackfruit Jam
}

\author{
Md. Arshad, K.R. Vasudeva", H.C. Krishna, T.H. Shankarappa and G.K. Halesh \\ Department of Postharvest Technology, College of Horticulture, University of Horticultural \\ Sciences Campus, GKVK, Bengaluru, Karnataka, India \\ *Corresponding author
}

\section{A B S T R A C T}

\section{Keywords}

Jackfruit jam, Protein fortified, Soya protein isolate and whey protein concentrate

Article Info

Accepted:

10 March 2018 Available Online:

10 April 2018
Changes in chemical and sensory characteristics of protein fortified jackfruit jam (2\% SPI and 2\% WPI) during three months storage at refrigeration temperature $\left(4^{\circ} \mathrm{C}\right)$ and ambient condition $\left(26-28^{\circ} \mathrm{C}\right)$ were studied. During storage, ascorbic acid, lycopene and protein content of the product decreased, whereas there was an increase in titratable acidity and total sugars in both the fortified jam under different storage conditions up to three months. The changes in physico-chemical parameters were more pronounced at ambient temperature as compare to refrigerated storage. The product was found to be nutritionally and microbiologically safe after three months of storage.

\section{Introduction}

Jackfruit (Artocarpus heterophyllus L.) belongs to the family Moraceae and it is a tropical evergreen tree. It is believed to be native of India, originated in Western Ghats and widely cultivated in Bangladesh, India, Myanmar, Malaysia, Sri Lanka, and other tropical countries.

The economical part of the fruit is bulb, which is used as dessert and processed in to various products such as papad and chips which can be stored and used round the year. The green, unripe, immature fruits are used for preparing vegetable curry, pickle, dried salted flakes and the seeds are processed into roasted nuts. Attempts have been made to process the jackfruit bulbs, nuts and rind into various products viz., canned bulbs in syrup, squash, papad, raw pickle, bar, leather, canned seeds in brine, roasted seeds and seed flour (Bhatia et al., 1956).

Jackfruit is available in plenty during the month of April-August and its market is highly unorganized and fruit is sold through road side stalls and also by push cart vendors. During the period of plenty of these fruits can be used for both fresh and processed products. Organized marketing and processing of bulb into jam is one important product especially 
for children. The advantage of jam is that it can be stored for longer period and can be easily fortified with protein, where it is much necessary for growing children.

For the last two decades, protein-energy malnutrition (PEM) and micronutrient deficiency has been subject of great concern to nutritionists and health authorities in developing countries. Among the available interventions for malnutrition, food-based approaches have been considered as most acceptable, safe and sustainable. These foodbased strategies include nutrition education, dietary diversification and food fortification. Supplementation still remains an important therapeutic intervention for critical deficiency status. Dietary diversification and nutrition educations are more long-term strategies and require lot of perseverance. In this context, food fortification is an effective and immediate way to target a widespread problem like protein energy under nutrition (Subbalakshmi and Naik, 1999).

The technology of fortification of baked products is advanced. However, limited information is available on the fortification of fruits and vegetable products. It was therefore, proposed to study the fortification of the jackfruit jam and its storage stability.

\section{Materials and Methods}

The jackfruits fruits were procured from jack garden, College of Horticulture, Kolar, Karnataka. Soy protein isolate (SPI) (SUPRO® XT 219D IP) was obtained from DuPont India private Limited, Gurgaon and Whey protein isolate (WPI) was procured from Lifecare Pharma chemists and druggist, BVK Iyengar road, Bengaluru.

Jam was prepared using the procedure given by Srivastava and Sanjeev (1997) with slight modifications during fortification with $2 \%$ SPI and 2\% WPI. Fortified jam samples were stored for three months under two conditions: (i) Refrigeration temperature $\left(4^{\circ} \mathrm{C}\right)$ and (ii) ambient temperature $\left(26-28^{\circ} \mathrm{C}\right)$.

Samples were analyzed for acidity by visual titration method, proteins by Micro-kjeldahl method, sugars by Lane and Eynon method, ascorbic acid by visual titration method and lycopene by spectrophotometer method (Ranganna, 1997). Sensory test was carried out after three months. The 8 panel members consisted of staff from college of Horticulture, Kolar. Four samples were presented to panelists in random order. Panelists were then asked to evaluate colour, flavour, taste and overall acceptability. The preference rating was scored on a 9 point Hedonic scale with 1 $=$ Dislike extremely and $9=$ Like extremely (Ranganna, 1997).

\section{Results and Discussion}

\section{Total titratable acidity}

There is a decreasing trend in total titratable acidity during storage at both ambient and refrigerated storage conditions. Total titratable acidity 90 days after storage was highest in non-fortified jackfruit jam as compared to protein fortified jams both in ambient as well as refrigerated storage conditions. Among the fortified jackfruit jam, acidity values were highest in 2 per cent whey protein fortified jam $(0.68 \%)$ as compared to 2 per cent soy protein fortified jam $(0.66 \%)$ and the jam fortified with 1 per cent SPI and 1 per cent WPI was recorded 0.67 per cent of titratable acidity. This could be due to chemical interaction between the organic constituents of the juice induced by temperature and action of enzymes (Palaniswamy and Muthukrishnan 1974; Nath et al., 2005). The decrease in acidity might also be due to hydrolysis of polysaccharides and non-reducing sugars where the acid is utilized for converting it into 
reducing sugars. Similar results have been recorded by Thakur et al., (1996) in tomato sauce enriched with soy protein and Kushala (2009) in the jackfruit jam blended with avocado and kokum (Table 1).

\section{Ascorbic acid}

There was a decreasing trend in ascorbic acid content during the storage period in all the treatments under both storage conditions. Under refrigerated storage condition, after three months of storage, the maximum retention of $42.10 \mathrm{mg} 100 \mathrm{~g}^{-1} \quad(9.94 \%$ loss $)$ ascorbic acid was recorded in control which was slightly higher than two per cent soy protein fortified jam $\left(40.73 \mathrm{mg} 100 \mathrm{~g}^{-1}\right)(9.18 \%$ loss). The decline in ascorbic acid concentration could be due to thermal degradation during processing and subsequent oxidation in storage as it is very sensitive to heat and pressure treatment, oxidation and light (Brock et al., 1998). Both ascorbic acid and dehydro ascorbic acid are highly volatile and unstable forms of vitamin-C. Similar findings were recorded by Kushala (2009) in jackfruit jam blended with avocado and kokum and Amruthesh (2012) in protein fortified tomato ketchup (Table 2).

\section{Total sugars}

Increasing trend was seen in the total sugars content of jams for both the storage conditions; increase in total sugars was more in ambient storage as compared to refrigerated storage. During three months of storage, it was observed that the total sugar content was highest in whey protein fortified jam $(66.33 \%)$ under ambient storage whereas the lowest $(61.65 \%)$ was recorded in jam fortified with two per cent soy protein isolate under refrigerated condition. The increase in reducing sugars was more in ambient storage as compared to refrigerated storage. During three months of storage it was observed that the reducing sugar content was highest in whey protein fortified jam $(38.60 \%)$ under ambient storage whereas the lowest $(27.27 \%)$ was recorded in jam fortified with two per cent soy protein isolate under refrigerated condition and the decreasing trend had seen in non-reducing sugar content (Table 3 ).

Increase in reducing and total sugars and decrease in non-reducing sugars during storage of products is a general phenomenon as observed by many workers, Amruthesh (2012) in protein fortified tomato ketchup and Kushala (2009) in jackfruit jam blended with avocado and kokum and Sangita et al., (2009) in bael squash using cheese whey and Bhatia and Pooja (2004) in protein enriched apple beverage and Singh and Nath (2004) in bael fruit beverage and Ismail et al., (2011) in whey based mango beverage and Sakhale et $a l .$, (2012) in whey and juice of mango.

\section{Total carotenoid}

The data revealed a decreasing trend in total carotenoid content with the advancement of storage period up to three months of storage. During the storage, maximum retention of $8.86 \mathrm{mg} / 100 \mathrm{~g}$ ( $14.23 \%$ loss) carotenoid content was recorded in jam fortified with two per cent whey protein isolate which was slightly higher as compared to non-fortified jackfruit

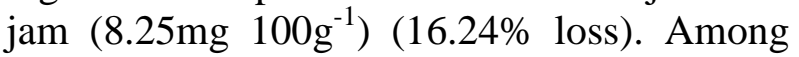
the two different storage conditions, significantly less carotenoid $\left(6.45 \mathrm{mg}_{\left.100 \mathrm{~g}^{-1}\right)}\right.$ (24.82\% loss) content was observed in jam fortified with 2 per cent soy protein isolate stored under ambient condition as compared to refrigerated storage $\left(7.14 \mathrm{mg} 100 \mathrm{~g}^{-1}\right)(16.78 \%$ loss) (Table 4).

Degradation of total carotenoid was more in case of jam stored at ambient condition as compared to low temperature storage. The loss of carotenoids increased at ambient storage temperature. 
Table.1 Changes in titratable acidity (\%) content of the protein fortified jackfruit jam during storage

\begin{tabular}{|c|c|c|c|c|c|c|c|}
\hline Treatments & Initial & \multicolumn{3}{|c|}{ Ambient condition } & \multicolumn{3}{c|}{ Refrigerated condition } \\
\cline { 3 - 8 } & & 30 & 60 & 90 & 30 & 60 & 90 \\
& & DAS & DAS & DAS & DAS & DAS & DAS \\
\hline Control & 0.87 & 0.83 & 0.78 & 0.73 & 0.85 & 0.83 & 0.81 \\
\hline 2\% SPI & 0.81 & 0.76 & 0.71 & 0.66 & 0.79 & 0.77 & 0.75 \\
\hline 2\% WPI & 0.83 & 0.78 & 0.73 & 0.68 & 0.81 & 0.79 & 0.77 \\
\hline 1\% SPI \& 1\% & 0.82 & 0.77 & 0.72 & 0.67 & 0.80 & 0.78 & 0.76 \\
\hline WPI & & & & & & & \\
\hline S Em \pm & $\mathbf{0 . 0 0 4}$ & $\mathbf{0 . 0 0 4}$ & $\mathbf{0 . 0 0 4}$ & $\mathbf{0 . 0 0 5}$ & $\mathbf{0 . 0 0 4}$ & $\mathbf{0 . 0 0 4}$ & $\mathbf{0 . 0 0 4}$ \\
\hline CD at 5\% & $\mathbf{0 . 0 1 3}$ & $\mathbf{0 . 0 1 4}$ & $\mathbf{0 . 0 1 4}$ & $\mathbf{0 . 0 1 6}$ & $\mathbf{0 . 0 1 3}$ & $\mathbf{0 . 0 1 4}$ & $\mathbf{0 . 0 1 4}$ \\
\hline
\end{tabular}

*Significant at $5 \%$

SPI: Soy Protein Isolate WPI: Whey Protein Isolate

DAS: Days after Storage

Table.2 Changes in ascorbic acid $\left(\mathrm{mg} 100 \mathrm{~g}^{-1}\right)$ content of the protein fortified jackfruit jam during storage

\begin{tabular}{|c|c|c|c|c|c|c|c|}
\hline \multirow{2}{*}{ Treatments } & Initial & \multicolumn{3}{|c|}{ Ambient condition } & \multicolumn{3}{c|}{ Refrigerated condition } \\
\cline { 3 - 8 } & & 30 & 60 & 90 & 30 & 60 & 90 \\
& & DAS & DAS & DAS & DAS & DAS & DAS \\
\hline Control & 46.75 & 44.83 & 42.90 & 40.80 & 45.45 & 44.15 & 42.10 \\
\hline $2 \%$ SPI & 44.85 & 42.95 & 40.98 & 39.25 & 43.58 & 42.28 & 40.73 \\
\hline 2\% WPI & 42.65 & 40.70 & 38.70 & 36.75 & 41.33 & 40.03 & 38.73 \\
\hline $\begin{array}{c}1 \% \text { SPI \& 1\% } \\
\text { WPI }\end{array}$ & 43.55 & 41.55 & 39.63 & 37.78 & 42.25 & 40.95 & 39.65 \\
\hline S Em \pm & $\mathbf{0 . 0 6 4}$ & $\mathbf{0 . 0 5 1}$ & $\mathbf{0 . 0 5 6}$ & $\mathbf{0 . 0 1 6}$ & $\mathbf{0 . 0 6 6}$ & $\mathbf{0 . 0 6 6}$ & $\mathbf{0 . 2 2 4}$ \\
\hline CD at 5\% & $\mathbf{0 . 1 9 8}$ & $\mathbf{0 . 1 5 8}$ & $\mathbf{0 . 1 7 5}$ & $\mathbf{0 . 3 2 9}$ & $\mathbf{0 . 2 0 6}$ & $\mathbf{0 . 2 0 6}$ & $\mathbf{0 . 6 9 2}$ \\
\hline
\end{tabular}

Table.3 Changes in total sugars $(\%)$ content of the protein fortified jackfruit jam during storage

\begin{tabular}{|c|c|c|c|c|c|c|c|c|}
\hline \multirow{2}{*}{ Treatments } & Initial & \multicolumn{3}{|c|}{ Ambient condition } & \multicolumn{3}{c|}{ Refrigerated condition } \\
\cline { 3 - 8 } & & 30 & 60 & 90 & 30 & 60 & 90 \\
& & DAS & DAS & DAS & DAS & DAS & DAS \\
\hline Control & 64.65 & 64.85 & 65.03 & 65.33 & 64.78 & 64.95 & 65.08 \\
\hline 2\% SPI & 61.25 & 61.53 & 61.73 & 62.00 & 61.38 & 61.50 & 61.65 \\
\hline 2\% WPI & 65.65 & 65.88 & 66.03 & 66.33 & 65.78 & 65.95 & 66.15 \\
\hline $\begin{array}{c}1 \% \text { SPI \& 1\% } \\
\text { WPI }\end{array}$ & 63.35 & 63.65 & 63.85 & 64.15 & 63.48 & 63.63 & 63.78 \\
\hline S Em \pm & $\mathbf{0 . 0 6 4}$ & $\mathbf{0 . 0 6 9}$ & $\mathbf{0 . 0 6 9}$ & $\mathbf{0 . 0 7 7}$ & $\mathbf{0 . 0 4 7}$ & $\mathbf{0 . 0 6 2}$ & $\mathbf{0 . 0 6 0}$ \\
\hline CD at 5\% & $\mathbf{0 . 1 9 8}$ & $\mathbf{0 . 2 1 5}$ & $\mathbf{0 . 2 1 4}$ & $\mathbf{0 . 2 3 7}$ & $\mathbf{0 . 1 4 7}$ & $\mathbf{0 . 1 9 2}$ & $\mathbf{0 . 1 8 6}$ \\
\hline
\end{tabular}

*Significant at $5 \%$

SPI: Soy Protein Isolate

WPI: Whey Protein Isolate

DAS: Days after Storage 
Table.4 Changes in total carotenoids $\left(\mathrm{mg} 100 \mathrm{~g}^{-1}\right.$ ) content of the protein fortified jackfruit jam during storage

\begin{tabular}{|c|c|c|c|c|c|c|c|}
\hline Treatments & Initial & \multicolumn{3}{|c|}{ Ambient condition } & \multicolumn{3}{c|}{ Refrigerated condition } \\
\cline { 3 - 8 } & & 30 & 60 & 90 & 30 & 60 & 90 \\
& & DAS & DAS & DAS & DAS & DAS & DAS \\
\hline Control & 9.85 & 9.00 & 8.33 & 7.73 & 9.25 & 8.49 & 8.25 \\
\hline $2 \%$ SPI & 8.58 & 7.80 & 7.05 & 6.45 & 8.03 & 7.69 & 7.14 \\
\hline 2\% WPI & 10.33 & 10.00 & 9.23 & 8.53 & 10.11 & 9.47 & 8.86 \\
\hline 1\% SPI \& 1\% & 9.45 & 9.10 & 8.43 & 7.80 & 9.05 & 8.62 & 8.29 \\
\hline WPI & & & & & & & \\
\hline S Em \pm & $\mathbf{0 . 0 3 3}$ & $\mathbf{0 . 0 4 0}$ & $\mathbf{0 . 0 5 2}$ & $\mathbf{0 . 0 5 1}$ & $\mathbf{0 . 0 5 8}$ & $\mathbf{0 . 1 7 2}$ & $\mathbf{0 . 1 7 7}$ \\
\hline CD at 5\% & $\mathbf{0 . 1 0 4}$ & $\mathbf{0 . 1 2 5}$ & $\mathbf{0 . 1 6 1}$ & $\mathbf{0 . 1 5 7}$ & $\mathbf{0 . 1 8 0}$ & $\mathbf{0 . 5 3 1}$ & $\mathbf{0 . 5 4 7}$ \\
\hline
\end{tabular}

Table.5 Changes in protein $(\%)$ content of the protein fortified jackfruit jam during storage

\begin{tabular}{|c|c|c|c|c|c|c|c|c|}
\hline \multirow{2}{*}{ Treatments } & Initial & \multicolumn{3}{|c|}{ Ambient condition } & \multicolumn{3}{c|}{ Refrigerated condition } \\
\cline { 3 - 8 } & & 30 & 60 & 90 & 30 & 60 & 90 \\
& & DAS & DAS & DAS & DAS & DAS & DAS \\
\hline Control & 1.30 & 1.25 & 1.20 & 1.14 & 1.27 & 1.24 & 1.20 \\
\hline 2\% SPI & 2.84 & 2.71 & 2.62 & 2.52 & 2.79 & 2.68 & 2.58 \\
\hline 2\% WPI & 2.82 & 2.64 & 2.54 & 2.49 & 2.69 & 2.60 & 2.53 \\
\hline 1\% SPI \& 1\% & 2.83 & 2.68 & 2.58 & 2.50 & 2.74 & 2.65 & 2.55 \\
\hline WPI & & & & & & & \\
\hline S Em \pm & $\mathbf{0 . 0 2 0}$ & $\mathbf{0 . 0 2 0}$ & $\mathbf{0 . 0 2 0}$ & $\mathbf{0 . 0 2 1}$ & $\mathbf{0 . 0 2 0}$ & $\mathbf{0 . 0 2 0}$ & $\mathbf{0 . 0 2 0}$ \\
\hline CD at 5\% & $\mathbf{0 . 0 6 3}$ & $\mathbf{0 . 0 6 3}$ & $\mathbf{0 . 0 6 4}$ & $\mathbf{0 . 0 6 6}$ & $\mathbf{0 . 0 6 3}$ & $\mathbf{0 . 0 6 3}$ & $\mathbf{0 . 0 6 3}$ \\
\hline
\end{tabular}

*Significant at $5 \%$

SPI: Soy Protein Isolate WPI: Whey Protein Isolate

DAS: Days after Storage

Table.6 Changes in sensory score of the protein fortified jackfruit jam during storage

\begin{tabular}{|c|c|c|c|c|c|c|c|c|}
\hline Treatments & \multicolumn{4}{|c|}{ Ambient condition } & \multicolumn{3}{c|}{ Refrigerated condition } \\
\hline & Colour & Flavour & Taste & $\begin{array}{c}\text { Overall } \\
\text { acceptability }\end{array}$ & Colour & Flavour & Taste & $\begin{array}{c}\text { Overall } \\
\text { acceptability }\end{array}$ \\
\hline Control & 8.60 & 8.46 & 8.25 & 7.72 & 8.75 & 7.75 & 8.64 & 8.31 \\
\hline $2 \%$ SPI & 7.70 & 7.41 & 7.83 & 7.60 & 7.35 & 7.63 & 7.84 & 7.60 \\
\hline 2\% WPI & 8.40 & 8.72 & 8.84 & 8.55 & 8.60 & 8.72 & 8.84 & 8.76 \\
\hline 1\% SPI \& & 8.10 & 8.15 & 8.22 & 7.93 & 8.20 & 7.90 & 8.25 & 8.12 \\
\hline $1 \%$ WPI & & & & & & & & \\
\hline S Em \pm & $\mathbf{0 . 0 4 0}$ & $\mathbf{0 . 0 3 0}$ & $\mathbf{0 . 2 0 5}$ & $\mathbf{0 . 0 2 0}$ & $\mathbf{0 . 0 2 9}$ & $\mathbf{0 . 0 2 0}$ & $\mathbf{0 . 0 0 4}$ & $\mathbf{0 . 0 2 0}$ \\
\hline CD at 5\% & $\mathbf{0 . 1 2 5}$ & $\mathbf{0 . 0 9 4}$ & $\mathbf{0 . 6 3 2}$ & $\mathbf{0 . 0 6 3}$ & $\mathbf{0 . 0 8 9}$ & $\mathbf{0 . 0 6 3}$ & $\mathbf{0 . 0 1 2}$ & $\mathbf{0 . 0 6 4}$ \\
\hline
\end{tabular}

It is well known that total carotenoids are relatively unstable to heat, oxygen and light.
Similar results were observed by Mondal et al., (2013) in jackfruit jam and Selvamuthukumar et 
al., (2003) in mixed fruit jam was prepared from blends of sea buckthorn (Hippophae rhamnoides) pulp and mango in ratio of 2:1.

\section{Protein}

The results obtained had revealed that there was a decreasing trend in protein content under both storage conditions. In refrigerated storage condition after three months, the retention of protein was more in jam fortified with 2 per cent soy protein isolate $(2.58 \%)$ and lowest in non-fortified jam (1.20\%). It was observed that under ambient condition the highest protein content retained was in the jam fortified with 2 per cent soy protein isolate $(2.52 \%)$ and lowest in non-fortified jam (1.14\%) (Table 5).

The variation in protein content may be due to the protein level used for the fortification. Similar results are observed by Alam et al., (2009) who found protein within the range of 1.91 to 2.42 per cent in tomato ketchup, Kamil et al., (2011) in ketchup and tomato paste, Vasudeva and Suresha (2010) in guava cheese and Agrahari et al., (2004) in protein enriched apple bar and Amruthesh (2012) in tomato ketchup fortified with 2 per cent soy protein isolate and 2 per cent whey protein isolate.

\section{Sensory qualities of fortified jackfruit jam} after three months of storage

The highest sensory score (8.76) for overall acceptability was recorded in jam fortified with 2 per cent whey protein isolate under refrigerated conditions and lowest sensory score (7.60) were recorded in jam fortified with 2 per cent soy protein isolate under both the storage. The overall acceptability for protein fortified jackfruit jam stored under refrigerated condition had the higher sensory score than ambient stored samples. Similar results were recorded by Amruthesh (2012) in protein fortified tomato ketchup and Kaushik et al., (2002) in bael fruit jam and Singh et al., (1983) in guava cheese and Rai (2001) also obtained higher score for guava cheese during second month of storage irrespective of storage conditions and Kushala,
(2009) in jackfruit jam and Safdar et al., (2012) in mango jam and Eke and Owuno (2013) in jackfruit jam (Table 6).

The changes in physico-chemical parameters were more pronounced at ambient temperature as compare to storage at refrigerated conditions in both the fortified products. Sensory evaluation revealed that jackfruit jam with $2 \%$ whey protein isolate was best compared to $2 \%$ soy protein fortified jam and non-fortified jam. During storage, the ascorbic acid, lycopene and protein content of the product decreased whereas there was increase in titratable acidity and total sugars in both the storage conditions up to three months. The product was found to be nutritionally and microbiologically safe after six months of storage.

\section{References}

Agrahari, P. R. 2001. Development of new products from cull apples and their quality evaluation. Ph.D thesis, IARI, New Delhi.

Alam, M. K., Ahmed, M., Akter, S., Nurul, I., Eun, J. B. 2009. Effect of carboxy methyl cellulose and starch as thickening agents on the quality of tomato ketchup. Pakistan J. Nutrition, 8(8): 1144-1149.

Amruthesh, C. 2012. Studies on the fortification of tomato (Solanum lycopersicum L.) ketchup and its storage. M. Sc. Thesis. UHS, Bagalkot.

Bhatia, A., Pooja C. 2004. Development of protein enriched apple beverage. J. Food Sci. Technol., 41(2): 174-177.

Bhatia, B. S., Siddappa, G. S., Lal, G. S. 1956. Physico-chemical changes in jackfruit squash during storage. Indian J. Agri. Sci., 26(4): 403-414.

Brock, V.D., Ludikhuyze, L., Weeemaes, C., Van, L.A., Hendrickx, M. 1998. Kinetics for isobaric isothermal degradation of LAscorbic acid. J. Agric. Food Chem., 46(5): 2001-2006.

Eke, E. J., Owuno, F. 2013. The physicochemical and sensory properties of 
jackfruit (Artocarpus heterophyllus) jam. Int. J. Nutri. Food Sci., 2(3): 149-152.

Ismail, A. E., Abdelgader, M. O., Ali, A. A. 2011. Microbial and chemical evaluation of whey-based mango beverage. $A d v$. $J$. Food Sci. Technol., 3(4): 250-253.

Kamil, M.M., Gamal, F., Mohamed, Shaheen, M.S. 2011. Fourier transformer infrared spectroscopy for quality assurance of tomato products. J. American Sci., 7(6): 206-216.

Kushala, G. 2009. Blended products of Jackfruit (Artocarpus heterophyllus Lam.) with Avocado and Kokum. M. Sc. Thesis, UAS, Bangalore.

Mondal, C., Remme, R. N., Mamun, A. A., Sultana, S., Ali, M. H., Mannan, M. A. 2013. Product development from jackfruit (Artocarpus heterophyllus) and analysis of nutritional quality of the processed products. J. Agri. Veterinary sci., 4 (1):76-84

Nath, A., Yadav, D.S., Pranabjyoti, S., Dey, B. 2005. Standardization of ginger-kinnow squash and its storage. J. Food Sci. Technol., 42(6): 520-522.

Palaniswamy, K. P., Muthukrishnan, C. R. 1974. Studies on physico-chemical characters of lemon juice and squash during storage. Indian Food Packer, 28 (4): 37-41.

Ranganna, S. 1997. Handbook of analysis and quality control for fruits and vegetable products. 2nd ed., Tata McGraw-Hill Publishing Co. Ltd., New Delhi.

Sakhale, B. K., Pawar, V. N., Ranveer, R. C. 2012.Studies on the development and storage of whey based RTS beverage from mango cv. Kesar. J Food Process. Technol., 3:148.

Sangita, S., Minhas, S., Manoranjan, K., Suruchi, K. 2009. Storage study of cheese whey and soy-whey based bael squash, Indian Food Packer, Jan-Feb. 25-29.

Selvamuthukumar, N. M., Farhathkhanum, Jeevarat, K., Ibhakar, H. S., Bawa, A. S. 2003. Functional fruit seabuck thorn pulp. In: $5^{\text {th }}$ International food convention held on $5^{\text {th }}$ December at CFTRI, Mysore, India.

Singh, R., Kapoor, A.C., Gupta, O.P. 1983. The effect of cultivars, seasons and storage on the nutritive value and keeping quality of guava cheese. Indian Food Packer, 37(5): 71-77

Srivastava, R.P., Sanjeev, K. 1994. Fruits and vegetable preservation-Principle and practices, $3^{\text {rd }}$ revised and enlarged edition. International book distributing Co., New Delhi

Subbalakshmi, G., Naik, M. 1999 Food fortification in developed countries current status and strategies. J. Food Sci. Technol., 36(5): 371-395.

Thakur, B. R., Rakesh, K., Avtar, K. H. 1996. Effect of added soy protein on quality of tomato sauce. J. Food Process. Preservation, 20: 169-176.

Vasudeva, K. R., Suresha, G. J. 2010. Protein enrichment of guava cheese using soy protein isolate and whey protein concentrate, J. Ecobiol., 26(1):55-60.

\section{How to cite this article:}

Md. Arshad, K.R. Vasudeva, H.C. Krishna, T.H. Shankarappa and Halesh, G.K. 2018. Effect of Storage Conditions on the Nutritional Quality of Protein Fortified Jackfruit Jam. Int.J.Curr.Microbiol.App.Sci. 7(04): 1018-1024. doi: https://doi.org/10.20546/ijcmas.2018.704.111 